\title{
Geochemical study of volcanic and associated granitic rocks from Endau Rompin, Johor, Peninsular Malaysia
}

\author{
Azman A Ghani ${ }^{1, *}$, Ismail Yusoff ${ }^{1}$, Meor Hakif Amir Hassan ${ }^{1}$ and Rosli Ramli ${ }^{2}$ \\ ${ }^{1}$ Department of Geology, University of Malaya, 50603 Kuala Lumpur, Malaysia. \\ ${ }^{2}$ Institute of Biological Science, University of Malaya, 50603 Kuala Lumpur, Malaysia. \\ *Corresponding author.e-mail: azmangeo@um.edu.my
}

Geochemical studies and modelling show that both volcanic and granitic magmas from the western part of the Johor National Park, Endau Rompin are different and probably have different sources. The geochemical plot suggests that both dacite/rhyolite and andesite probably have a common origin as in many of the geochemical plots, these two groups form a similar trend. Volcanic rocks have a transitional geochemical character between tholeiite and calc alkaline on a $\mathrm{Y}$ versus $\mathrm{Zr}$ plot. $(\mathrm{La} / \mathrm{Yb})_{\mathrm{N}}$ versus La and $\mathrm{TiO}_{2}$ versus $\mathrm{Zr}$ modelling show that the crystallization of both granitic and volcanic magmas are controlled by a different set of minerals. The rare earth elements (REE) patterns of some of the granite and volcanic samples have pronounced negative Eu anomaly indicating plagioclase fractionation. The difference between both profiles is that the granite samples show a concave shape profile which is consistent with liquids produced by partial melting of quartz feldspathic rocks containing amphibole among the residual phase. Both magmas were generated at a different time during the subduction of Sibumasu beneath the Indochina blocks.

\section{Introduction}

During the Permian-Late Triassic period, widespread magmatic activity developed in Peninsular Malaysia following the continental collision between the Sibumasu and Indochina blocks. The Permo-Triassic subduction constructed an accretionary complex of offscraped oceanic sediments and melange, and also produced the East Malaya Volcanic Arc and I-type granitoids. This produced both intrusive and extrusive rocks, which appear to be associated in space and time, as exemplified from the Central and Eastern Belts of Peninsula Malaysia (Cobbing et al. 1992). The contemporaneous association of volcanic or subvolcanic rocks with granitic bodies are not uncommon (Ghani 2009). In central and eastern Johor, volcanic lavas and pyroclastic rocks are closely associated with granitic rock. In the south of Peninsular Malaysia, the volcanic rocks, especially the lava type, usually occur in close association with the I-type granitic rock. The study area is part of the Endau Rompin National Park, Johor State, located in the southern part of Peninsular Malaysia. The relationship between both volcanic and their granitic counterparts is crucial as the former can indicate the character of near-liquidus phases (Atherton et al. 1992). The knowledge on both magmatic complexes in this part of Peninsular Malaysia is very limited. The relationships among the volcanic, plutonic

Keywords. Endau Rompin; Peninsular Malaysia; rare earth elements; granite; volcanic arc. 
and their age surrounding sedimentary rocks are not clearly established. Their petrogenetic characteristics and tectonic settings are poorly known. Detailed study of the petrological and geochemical data obtained from volcanic and granitic rocks may provide us some information about the geodynamics of the study area. All these aspects will be discussed in this paper along with detailed geochemical study of major trace and rare earth elements.

\section{General geology}

The development of a volcanic arc (referred to as the Lanchang Volcanic Arc) during the Permo-Triassic in Peninsular Malaysia was largely related to the subduction of Sibumasu beneath the Indochina blocks (Hutchison 1977; Metcalfe 2000). The subduction was associated with the closure of the Palaeo-Tethys, now represented by the Bentong-Raub Suture Zone (Metcalfe 2000). In the southern part of Peninsular Malaysia, the Permian and Carboniferous volcanic rocks are dominated by felsic to intermediate pyroclastic, lava and ignimbrite mainly of rhyolitic to dacitic composition. In north central Johor, the felsic rock dominated by granitic rock that forms the Besar batholith are closely associated with the Permian volcanic rocks known as the Jasin Volcanic (Chong et al. 1968). The area also known as Endau Rompin, is designated as Johor State National Park (figure 1). Stratigraphy of the Endau Rompin area can be divided into three main units: Jasin Volcanics, granites and sedimentary rocks of the Tebak Formation (figure 1). Based on its stratigraphic position, Foo (1969) and others (e.g., Hutchison and Tan 2009) suggested a Late Permian to Triassic age for the Jasin Volcanics. The rock types are mainly pyroclastic and felsic lava (rhyolite and dacite). They usually occur as an interbedded sequence with other layered rocks or as massive type lava.

The granitic rock occurs as N-S trending batholiths also known as Besar batholiths. It is part of the Eastern Belt granite and located at the east of the Bentong-Raub Suture. The granite is composed of pink, fine to coarse-grained biotite hornblende granodiorite. The age of the granite has been dated as 213 to 215 Ma based on K-Ar and $\mathrm{Rb}-\mathrm{Sr}$ methods (Bignell and Snelling 1977). The younger age of the granitic rocks is supported by the occurrence of angular and sub-angular granitic block in the volcanic rocks. The average sizes of the granitic blocks range from 2 to $6 \mathrm{~cm}$ in diameter. The Tebak Formation was deposited during the Late Jurassic to Early Cretaceous which lies comformably on top of the granite and volcanics.
The study area is located in the west of the Endau Rompin National Park. Simplified geological map for the study area is shown in figure 1.

\section{Petrography}

\subsection{Granite}

The dominant minerals in decreasing abundance are quartz (27-40\%), K-feldspar (28-38\%), plagioclase $(22-28 \%)$, biotite $(5 \%)$ and hornblende (3-4\%). The accessory minerals are zircon, apatite, allanite, sphene and rutile. The rock can be classified as granite and granodiorite following the Streckeisen classification (1976). Quartz occurs as anhedral crystals with average sizes of 0.1 to $0.6 \mathrm{~cm}$ across. It shows embayed boundaries or irregular outlines (figure 2b). Plagioclase is equigranular, subhedral to anhedral with average sizes of 0.1 to $0.5 \mathrm{~cm}$ in length. Normal and oscillatory zoning are common and inclusion of zircon, apatite, biotite, opaque muscovite and quartz were observed. Microcline microperthite is the main K-feldspar type and usually occurs as subhedral to anhedral crystals with average sizes of 0.2 to $2.5 \mathrm{~cm}$ across. Sometimes, it occurs as interstitial crystals between plagioclase grains. Subhedral to anhedral biotite occurs as elongate crystals or aggregates associated with hornblende and sphene. Its pleochroic scheme is $\mathrm{X}=$ dark brown and $\mathrm{Y}=$ brown. Sometimes, the mineral is altered to chlorite at the margin. Hornblende usually occurs as euhedral to anhedral crystals. Its common pleochroic scheme is $\mathrm{X}=$ light yellowish green, $\mathrm{Y}=\mathrm{Z}=$ dark green. Euhedral to subhedral sphene is the most common accessory mineral and is preferentially associated with hornblende and biotite. Apatite occurs as inclusions in hornblende, biotite, plagioclase, quartz and microcline. It occurs in two habits, i.e., small prismatic to acicular crystals and euhedral to anhedral squat-shaped crystals. Other accessory minerals present are euhedral zoned allanite (figure $2 \mathrm{a}$ ) and zircon.

\subsection{Volcanic rock}

Volcanic rock in the study area can be divided into two types: lava and pyroclastic. The pyroclastic rocks exhibit a broad variation in both colour and texture. The main pyroclastic types contain various blocks of up to $0.5 \mathrm{~m}$ in diameter (figure $2 \mathrm{f}$ ). The blocks are sometimes flattened due to the magmatic movement (figure 2e). Traces of flow structure can be recognized particularly around crystals or lithic fragments. The lava is usually composed of massive fine-grained rhyolitic rocks and is grey to pink in colour. The rocks are porphyritic, with 


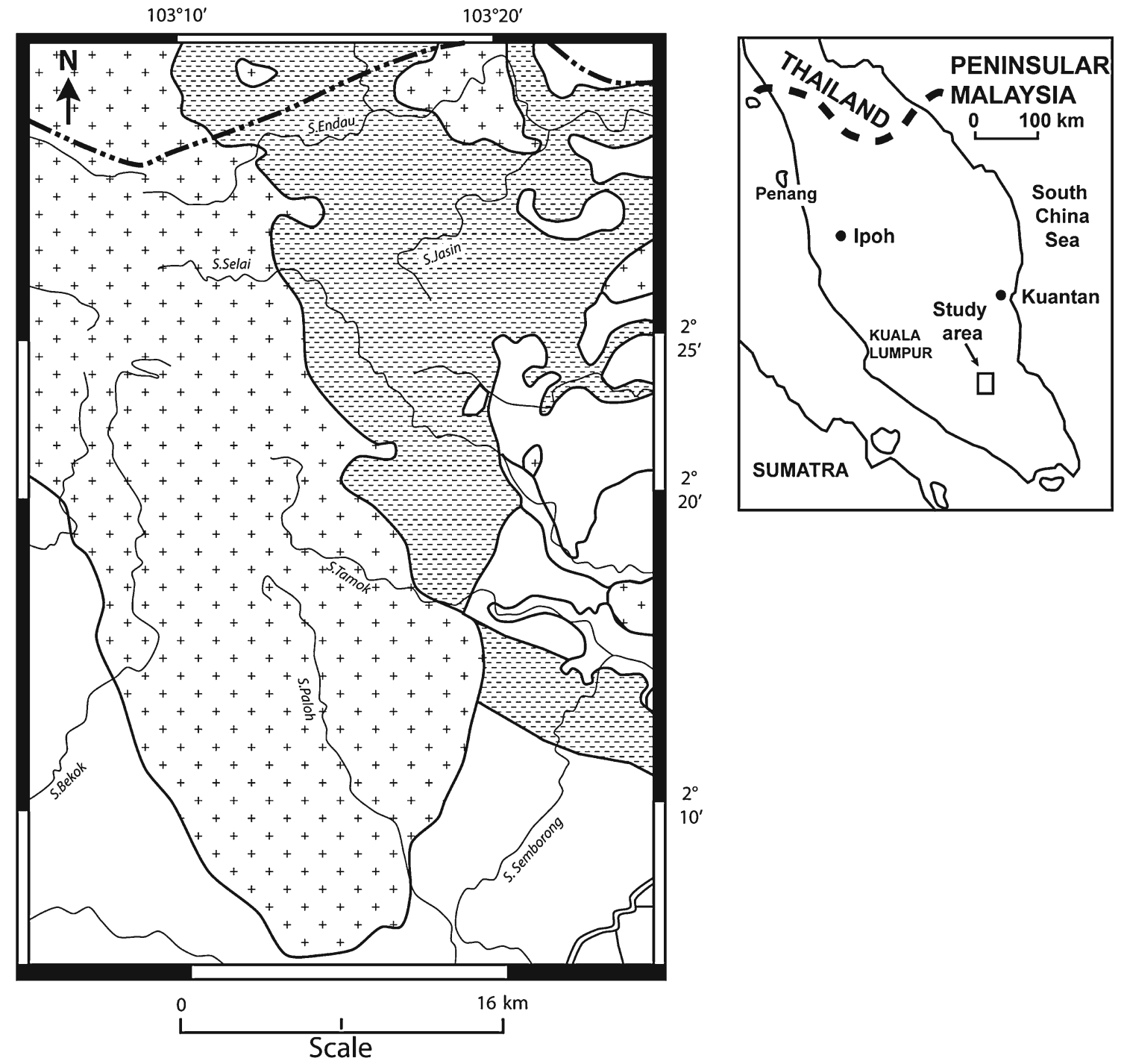

\section{LEGEND}

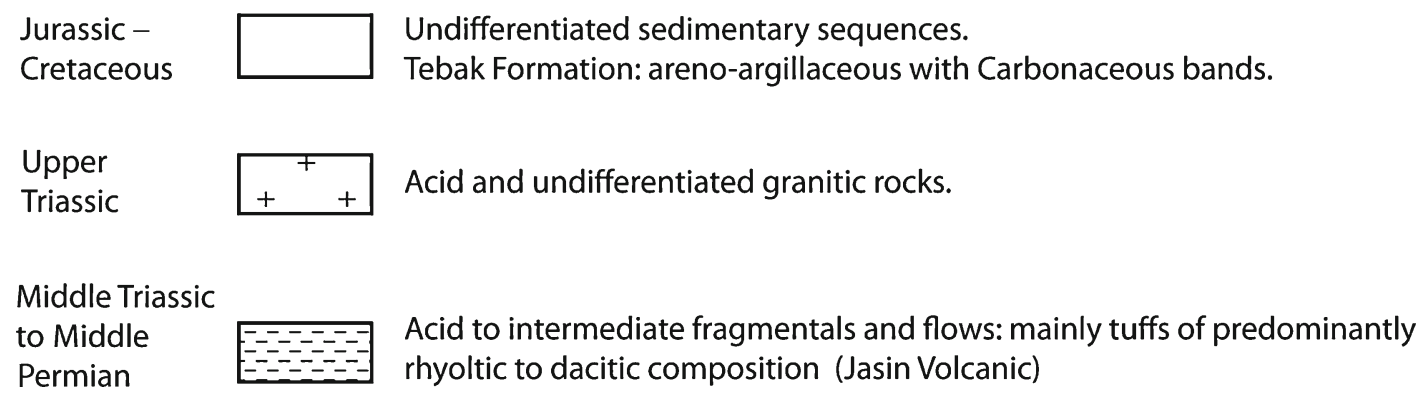

Figure 1. Simplified geological map of the west Endau Rompin area shows the relationship between granite and volcanic rocks. General stratigraphy of the area is shown in the legend of the map. Modified from Ghani et al. (2007).

abundant quartz and feldspar phenocrysts of up to $2 \mathrm{~mm}$ in diameter set in a fine-grained matrix of the same composition. Euhedral to anhedral quartz phenocrysts commonly show embayed texture due to the magmatic corrosion (figure $2 \mathrm{c}, \mathrm{d}$ ). This suggests that they may have been formed by intratelluric crystallization at depth before the extrusion of the volcanic lava. Glomeroporphyritic texture is usually formed by euhedral plagioclase crystals with maximum length of $1.5 \mathrm{~mm}$. Alteration of biotite to secondary chlorite is common. 

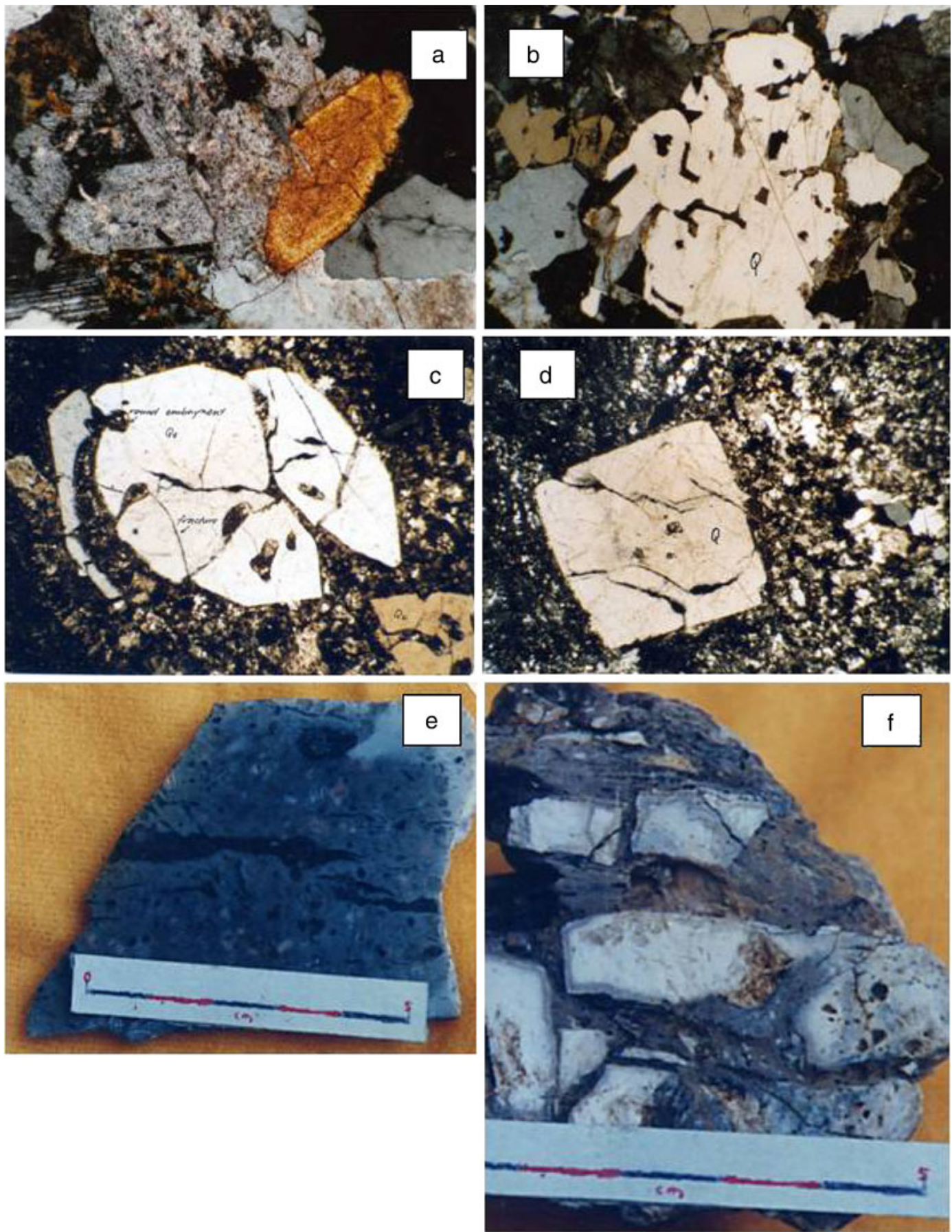

Figure 2. Field and texture of the granite and volcanic rocks from the study area. (a) Photomicrograph of the granitic rocks from the study area showing chloritized biotite, sericitized plagioclase and euhedral zoned allanite, (b) embayed quartz crystal in the granite, (c) embayed and crackquartz phenocrysts set in the fine grained groundmass (volcanic rock), (d) euhedral quartz phenocrysts in volcanic rock, (e) photograph of the volcanic rock hand specimen showing flattened foreign material due to magma movement and (f) volcanic rocks consisting of various sizes of block of different origin. Photomicrograph by Munawir Muslim.

\section{Geochemistry}

\subsection{Sample preparation}

A total of 30 samples (15 granite and 15 volcanic) was collected for this study. The samples weighed about 0.5 to $1 \mathrm{~kg}$ and were firstly trimmed in order to remove any altered/weathered material. The cleanest and freshest samples were split into $1 \mathrm{~cm}$ cubes using a hydraulic jaw-splitter washed to remove dust and were dried (at room temperature) overnight. Glass fusion discs were used in the analysis of major elements. Each disc was prepared by using a mixture of approximately $0.5 \mathrm{~g}$ 


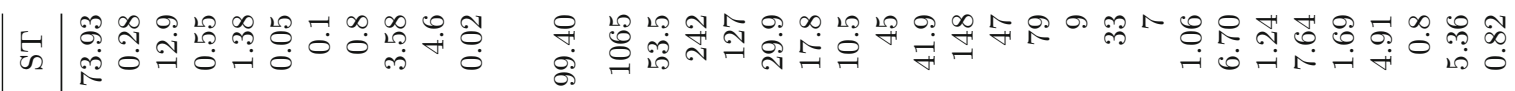

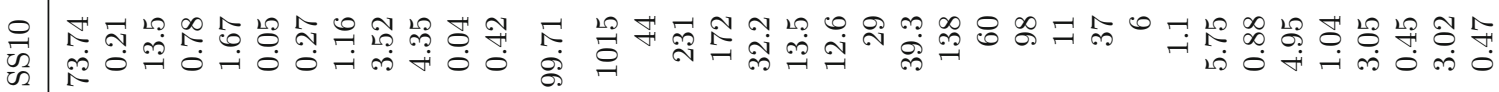

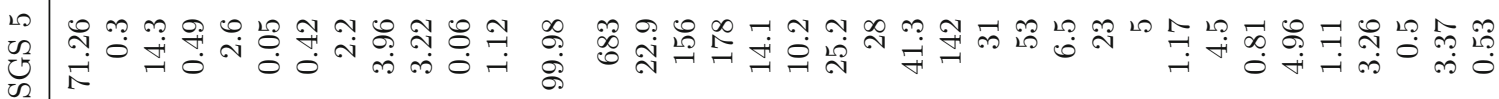
至

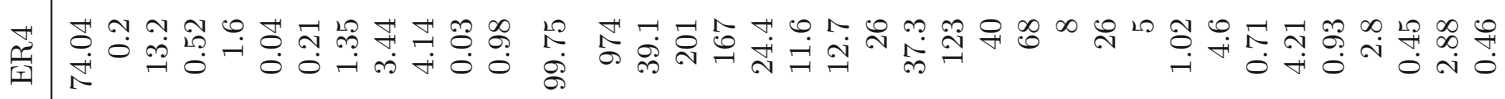

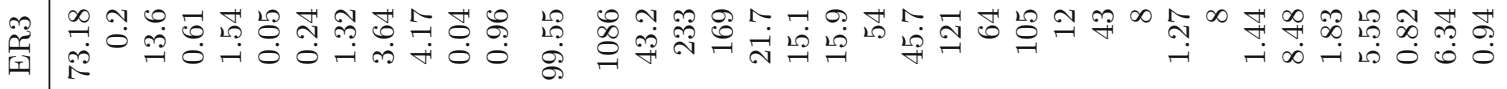

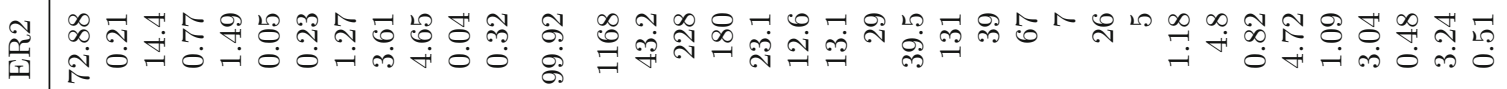
䓛

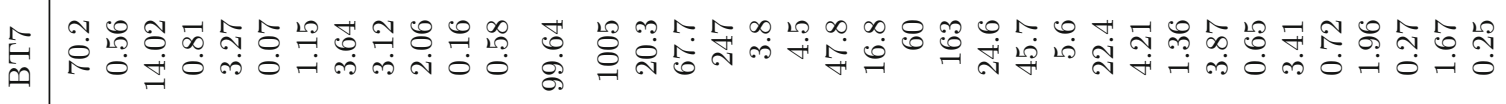

舟

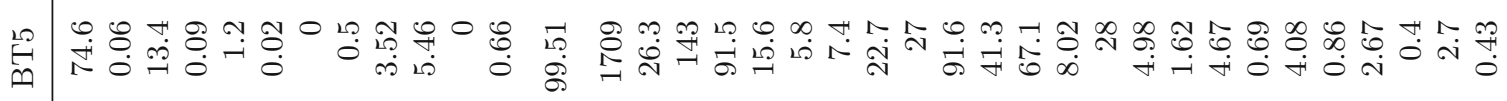

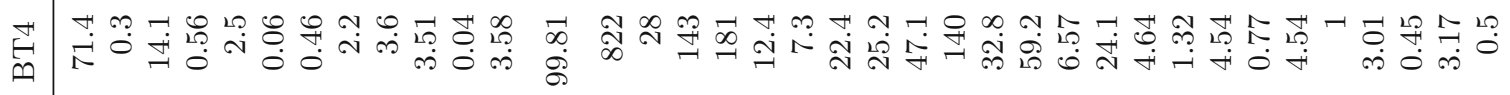

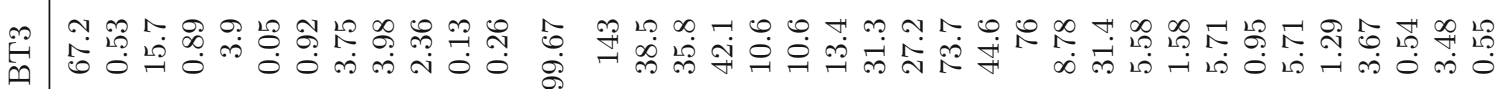
网

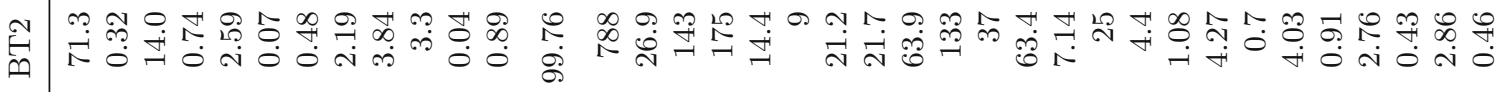

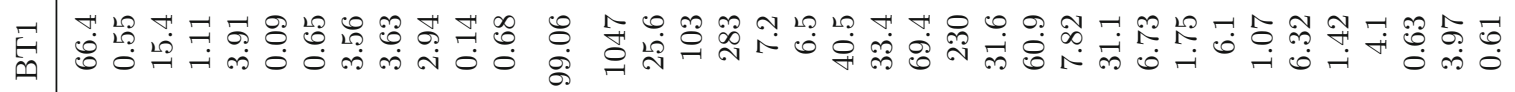

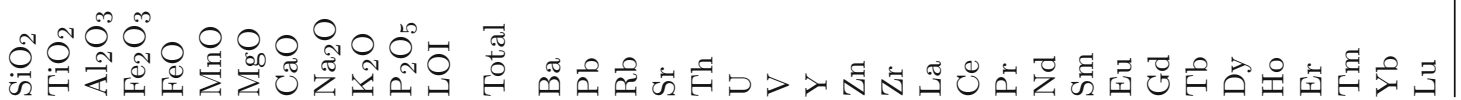




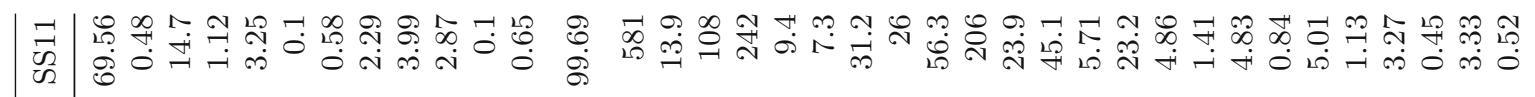

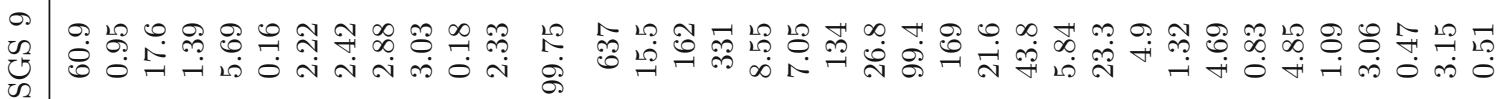

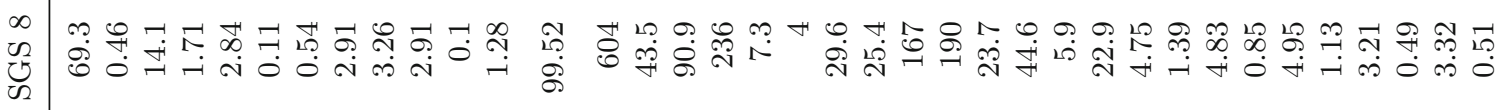

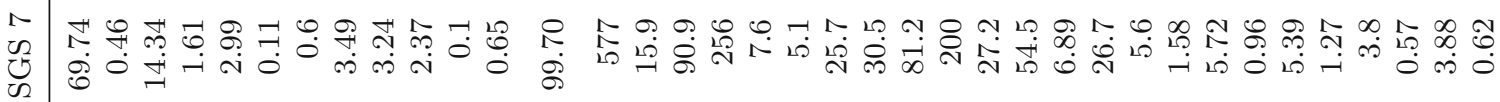

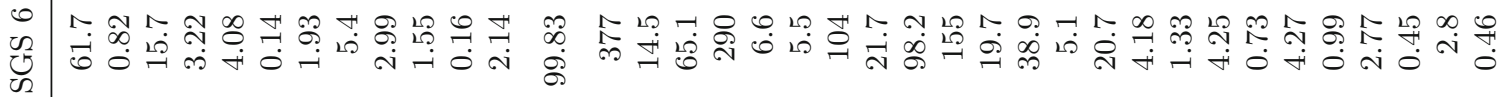

サn

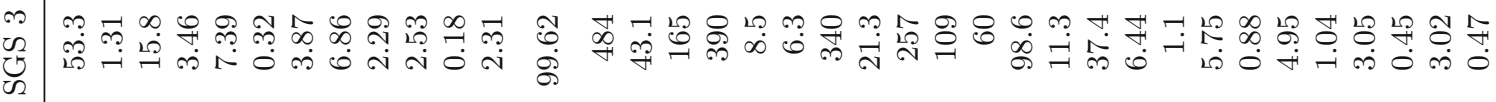

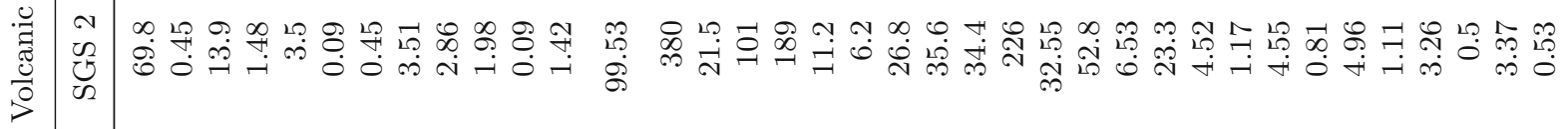

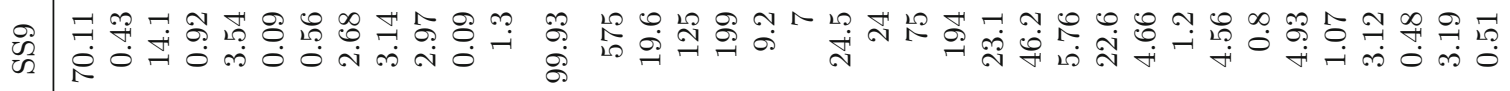

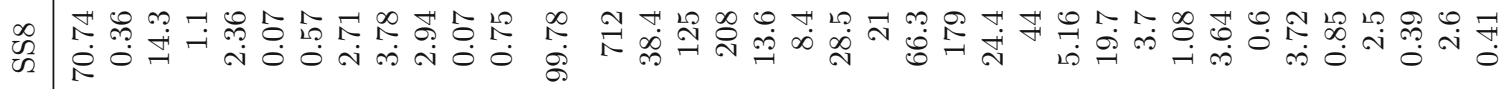

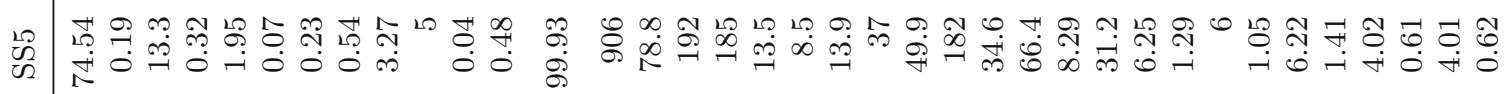

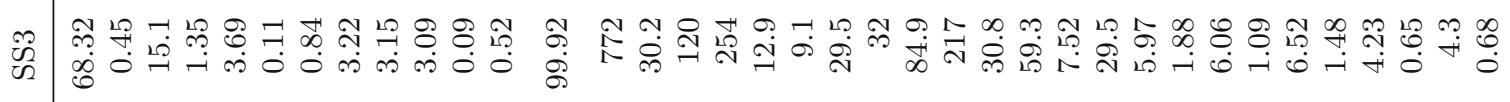

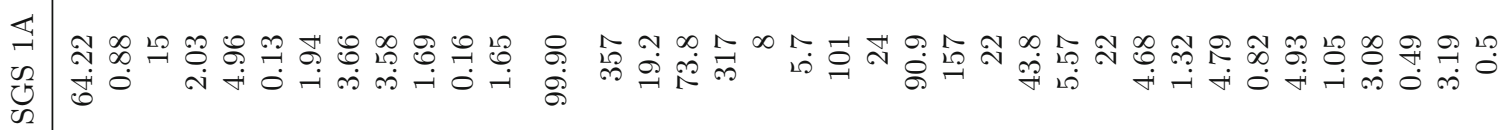

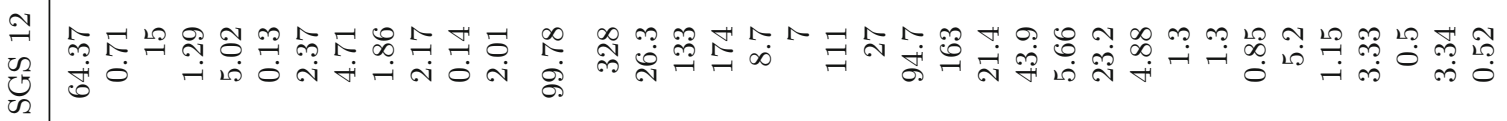

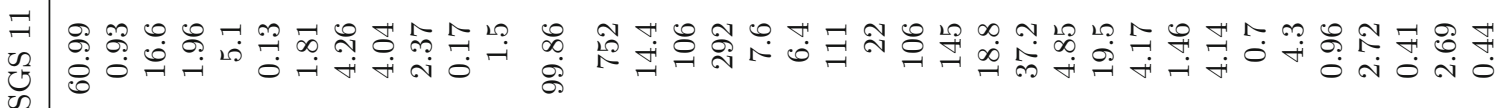

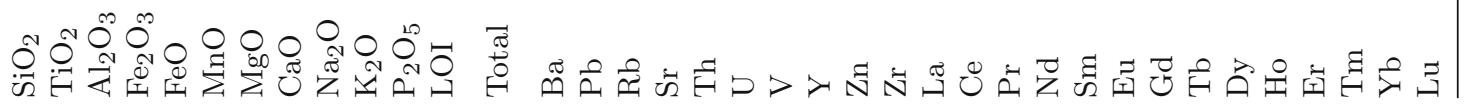


(weighed to 4 decimal places) of 153 micron rock powder with $3.3 \mathrm{~g}$ of lithium borate flux in a ratio of 5.4321 : 1 flux : rock, at $1150^{\circ} \mathrm{C}$ and the melt casted on to $4 \mathrm{~cm}$ diameter aluminium plates. The resultant glass disc was then mounted on a backing disc for analysis. Powder pellets used in trace elements analysis, were prepared by mixing $7 \mathrm{~g}$ of 53 micron powder with 12 to 15 drops moviol binder solution (4 g Moviol $+10 \mathrm{ml}$ ethanol $+50 \mathrm{ml}$ distilled water). The resultant mixture was pressed into a $4 \mathrm{~cm}$ disc under 5 tons pressure and dried before analysis.

Major oxide elements $\left(\mathrm{SiO}_{2}, \mathrm{TiO}_{2}, \mathrm{Al}_{2} \mathrm{O}_{3}\right.$, $\mathrm{Fe}_{2} \mathrm{O}_{3}, \mathrm{MgO}, \mathrm{MnO}, \mathrm{CaO}, \mathrm{Na}_{2} \mathrm{O}, \mathrm{K}_{2} \mathrm{O}$ and $\mathrm{P}_{2} \mathrm{O}_{5}$ ) and trace elements (Ba, Ce, La, Cr, Nd, Nb, Ni, $\mathrm{Pb}, \mathrm{Rb}, \mathrm{Sc}, \mathrm{Sr}, \mathrm{Th}, \mathrm{V}, \mathrm{Y}, \mathrm{Zn}$ and $\mathrm{Zr}$ ) were analysed by X-Ray Fluorescence Spectrometer 3080E of Japanese Rigaku Industrial Corporation with RSD (relative standard deviation) $\leq 3 \%$ at the National Research Center of Geoanalysis of China.

For $\mathrm{FeO}$, the $\mathrm{K}_{2} \mathrm{Cr}_{2} \mathrm{O}_{7}$ titration was used with $\mathrm{RSD} \leq 5 \%$;

For $\mathrm{CO}_{2}$, coulometry was used with $\mathrm{RSD} \leq 10 \%$; and

For $\mathrm{H}_{2} \mathrm{O}^{+}$, gravimetry was used with $\mathrm{RSD} \leq 5 \%$.

The powder of the samples was then shaken and dried at $110^{\circ} \mathrm{C}$ for 12 hours. The REE concentration was determined by using inductive couple plasma (ICP) at the National Research Centre of Geoanalysis, Chinese Academy of Geological Sciences, Beijing. $0.25 \mathrm{~g}$ of powdered rock was weighed accurately into a graphite crucible and $2 \mathrm{~g} \mathrm{Na}_{2} \mathrm{O}_{2}$ was added. The mixture was heated at $700^{\circ} \mathrm{C}$ for
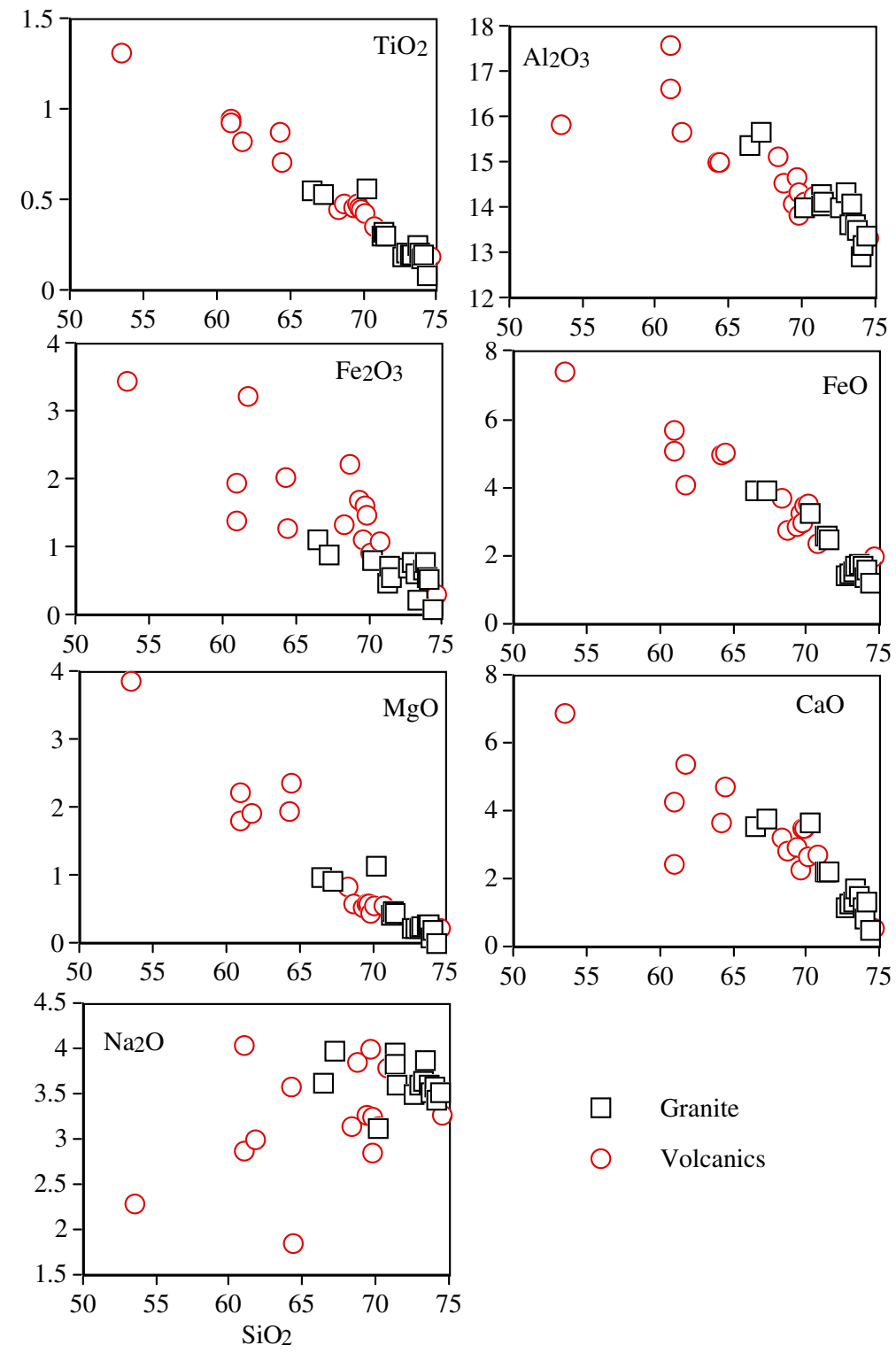

Granite

Volcanics

Figure 3. Selected major elements Harker plots for volcanic and granite from the study area. 
about an hour and then extracted and leached with water. The precipitation of hydrated oxide was dissolved with $\mathrm{HNO}_{3}$ and analysed using ICP-MS.

\subsection{Result and discussion}

Results of the 15 samples each from the volcanic and granitic rocks are shown in table 1. Major and trace elements Harker diagrams are shown in figures 3 and 4 . The range and mean of $\mathrm{SiO}_{2}$ of the volcanic and granitic rocks from the Endau Rompin are; volcanic: $53.3-74.54 \% \mathrm{SiO}_{2}$ and granite: $66.42-74.35 \% \mathrm{SiO}_{2}$ (figure 3). $\mathrm{TiO}_{2}, \mathrm{Al}_{2} \mathrm{O}_{3}$, $\mathrm{Fe}_{2} \mathrm{O}_{3}, \mathrm{Feo}, \mathrm{CaO}$ and $\mathrm{MgO}$ for both volcanic and granitic rocks decrease with increasing $\mathrm{SiO}_{2}$. All rocks from both units generally have high alkaline contents $\left(\mathrm{Na}_{2} \mathrm{O}+\mathrm{K}_{2} \mathrm{O}\right)$ ranging from 5.18-8.98 $\mathrm{wt} \%$ for granite and 4.03-8.27 wt\% for volcanic rock. Plots of $\mathrm{Na}_{2} \mathrm{O}+\mathrm{K}_{2} \mathrm{O}$ versus $\mathrm{SiO}_{2}$ (total alkali silica (TAS) diagram) (Le Bas et al. 1986; LeMaitre 2002) show that majority of the volcanic samples lie within the andesite, dacite and rhyolite fields (figure 5).
On a $\mathrm{K}_{2} \mathrm{O}$ versus $\mathrm{SiO}_{2}$ diagram (figure 6), the granite samples plot in the high-K calc alkali field, similar to the other Eastern Belt granite magmas, whereas the volcanic rocks straddle between high$\mathrm{K}$ calc alkali and calc alkali field. Roberts and Clemens (1993) showed that a parent magma with given $\mathrm{K}_{2} \mathrm{O}$ and $\mathrm{SiO}_{2}$ contents will evolve within the particular field in a $\mathrm{K}_{2} \mathrm{O}$ versus $\mathrm{SiO}_{2}$ diagram and for magma to evolve into an adjacent field, some process other than crystal-liquid separation must operate. This clearly indicates that the granitic and volcanic rocks are very different and probably have different sources. The volcanic rocks have lower Ba (mean: $581 \mathrm{ppm})$, but higher Sr content (mean: $254 \mathrm{ppm}$ ) content compared to granitic (Ba: mean 891 ppm and Sr: mean 167 ppm). In a Ba versus Sr plot, both granitic and volcanic rocks plot in two different areas, majority of the latter plot above the $\mathrm{Sr}=200 \mathrm{ppm}$ line. Precipitation of plagioclase is also evidenced from $\mathrm{Rb} / \mathrm{Sr}$ versus $\mathrm{SiO}_{2}$ plot (Ghani et al. 2007). The plot shows a ' $J$ '-shaped trend, which suggests the importance of the fractional crystallization process with
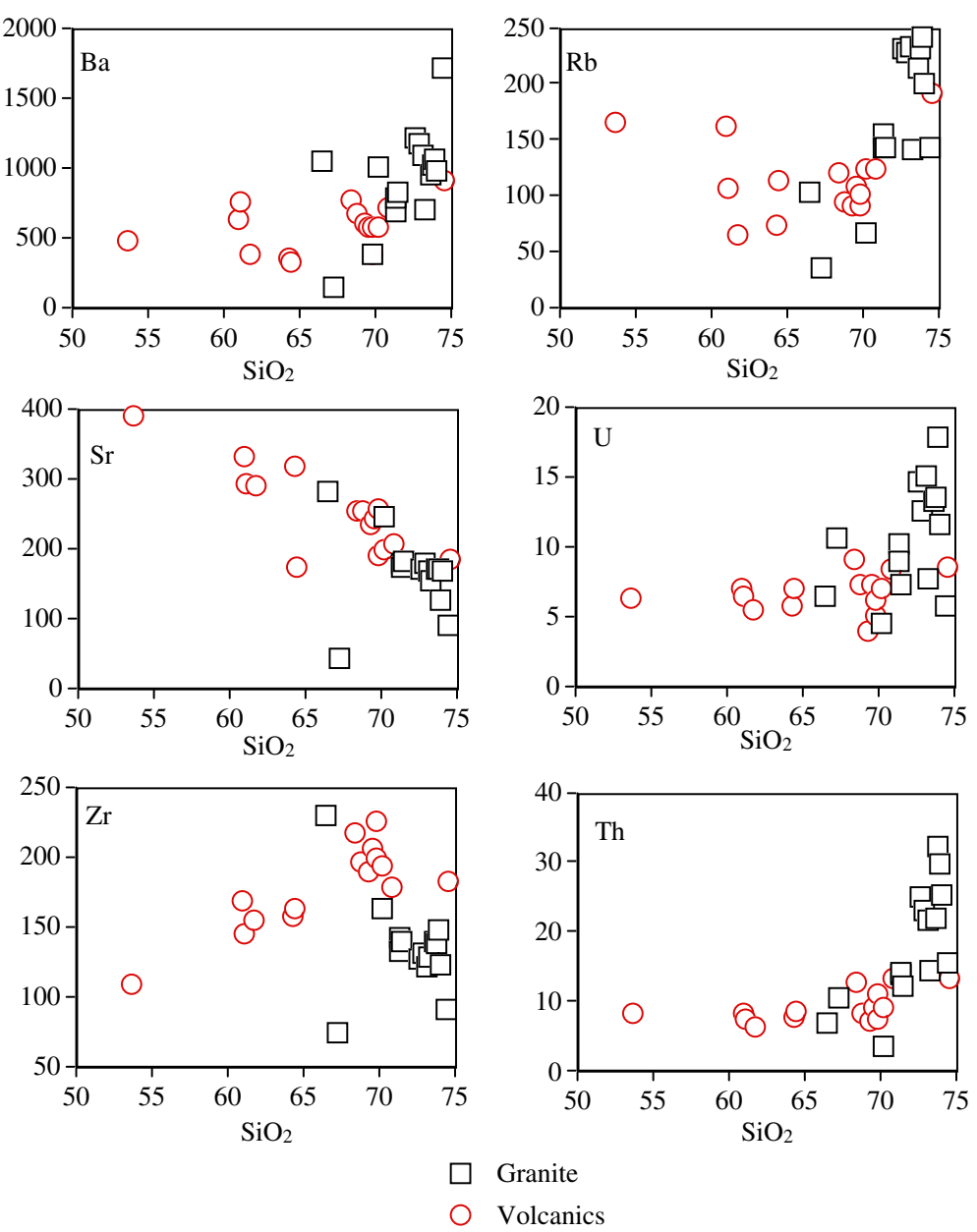

Figure 4. Selected trace elements Harker plots for volcanic and granite from the study area. 


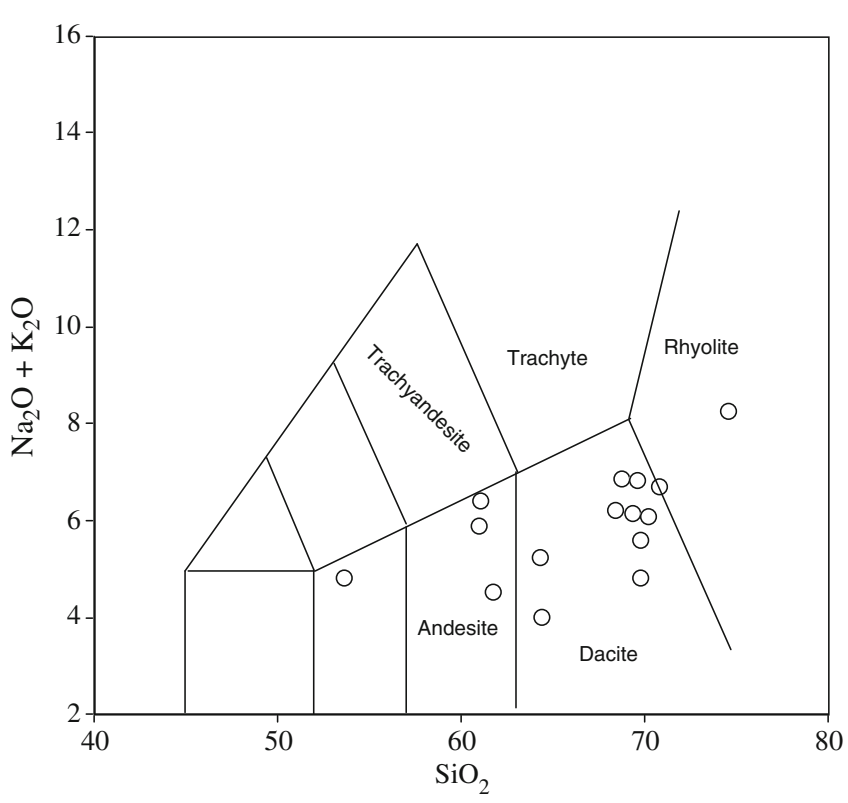

Figure 5. Classification of the volcanic rocks from the study area using $\mathrm{Na}_{2} \mathrm{O}+\mathrm{K}_{2} \mathrm{O}$ versus $\mathrm{SiO}_{2}$ diagram.

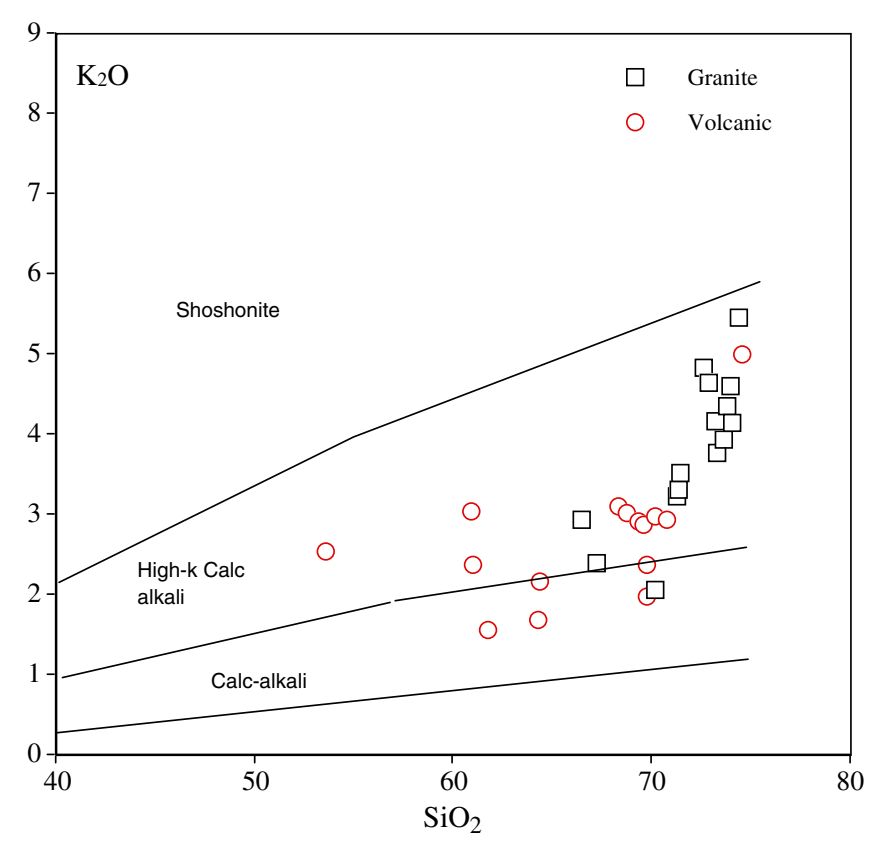

Figure 6. $\mathrm{K}_{2} \mathrm{O}$ vs. $\mathrm{SiO}_{2}$ diagram of the volcanic and granitic rocks from the western part of Johor National Park, Endau Rompin. Note the different trends shown by both rocks.

plagioclase as the major precipitating phase in both granitic and volcanic magmas.

The $\mathrm{TiO}_{2}$ versus $\mathrm{Zr}$ plot (figure 7) shows the different crystallizing options in the granite and volcanic rocks. General trends of the granitic rocks seem to be controlled by some combination of the crystallization of zircon + sphene, zircon + hornblende, zircon + magnetite, zircon + biotite + hornblende and zircon + hornblende + sphene +

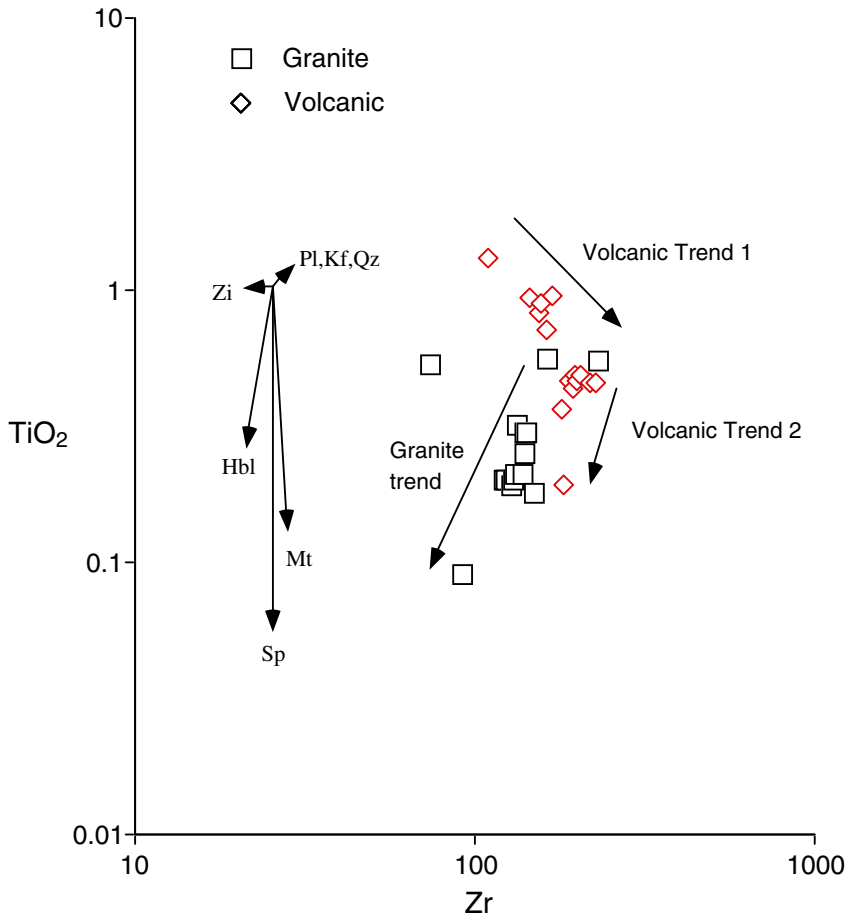

Figure 7. $\mathrm{TiO}_{2}$ vs. $\mathrm{Zr}$ plot of the volcanic and granitic rocks from Johor National Park, Endau Rompin. Mineral vectors indicate path evolved liquids for $15 \%$ of a mineral precipitating: $\mathrm{Pl}=$ plagioclase $\mathrm{Kf}=\mathrm{K}$-feldspar; $\mathrm{Qz}=$ quartz; $\mathrm{Mt}=$ magnetite; $\mathrm{Sp}=$ sphene; $\mathrm{Hbl}=$ hornblende; $\mathrm{Bi}=$ biotite; $\mathrm{Zi}=$ zircon.

magnetite. The volcanic rocks show two different trends, early crystallization (trend 1) seems to be controlled by more felsic mineral (plagioclase, Kfeldspar and quartz), whereas zircon, hornblende, sphene and magnetite seems to control the late crystallization of volcanic magma (trend 2). Thus, the trend 1 is controlled by combination of plagioclase + K-feldspar + quartz + magnetite + sphene and trend 2 controlled is by combination of zircon + hornblende + sphene + magnetite.

Fourteen REE elements from La to Lu were analysed for each sample. The REE data for granitic and volcanic rocks are shown in table 1 . REE concentrations for the chondrite Leedy (Masuda et al. 1973) were used for normalization. The volcanic rock has low total REE (102.3-234.5 ppm; mean: $139.98 \mathrm{ppm}$ ) content compared to the granite (116-266; mean: $180 \mathrm{ppm})$. In general, total REE in both volcanic and granite increases with increasing $\mathrm{SiO}_{2}$ (figure 8). All samples are generally enriched in light rare earth elements (LREE) and depleted in heavy rare earth elements (HREE) (figures 9 and 10). One of the most surprising features of the REE data for both granitic and volcanic rocks is the similarity of both chondrite normalized profiles; they both show a family-like profile. The difference is that the granite profile has a wide range of the HREE compared to the volcanic 


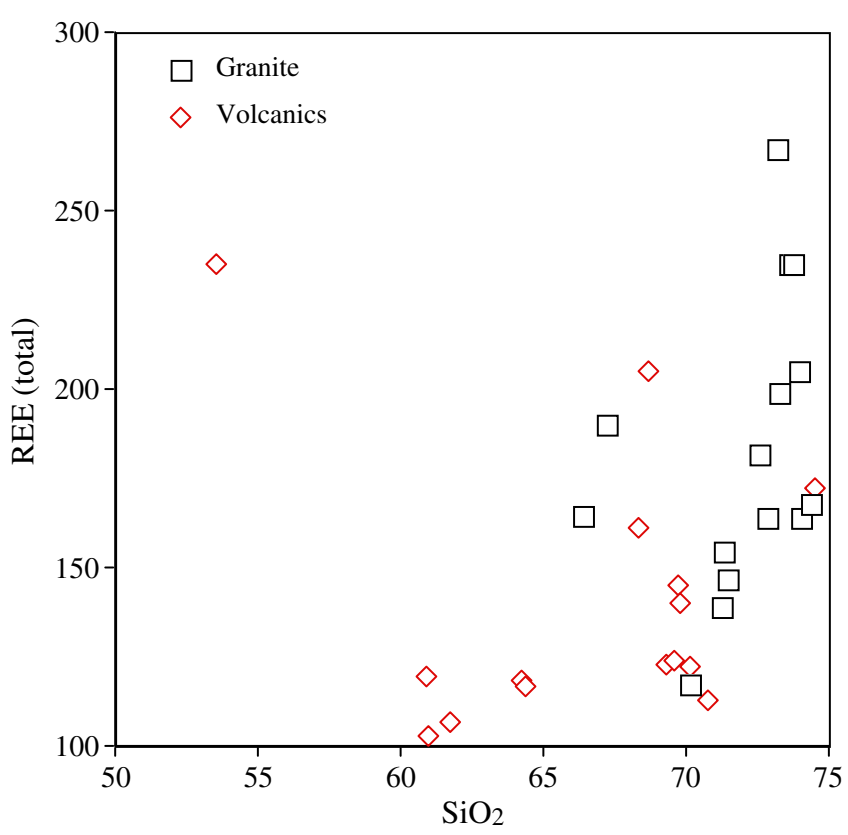

Figure 8. Total REE vs. $\mathrm{SiO}_{2}$ content of both granite and volcanic.

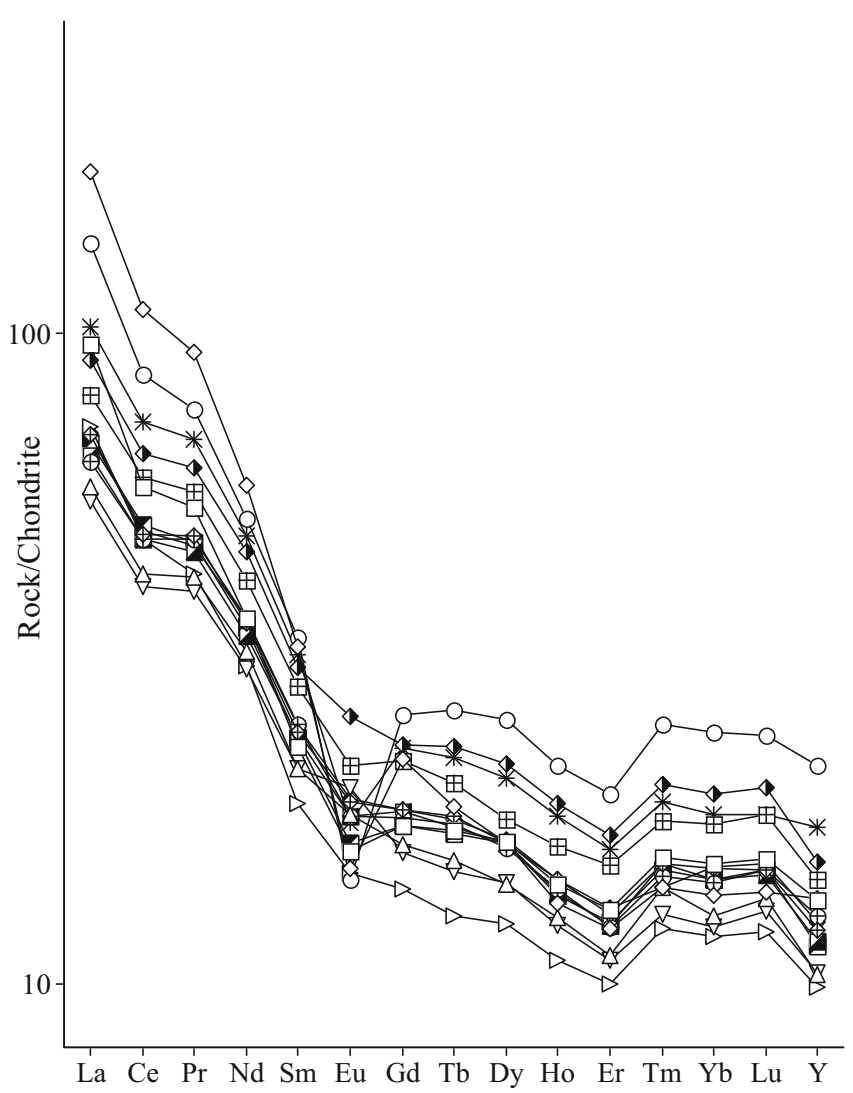

Figure 9. Chondrite normalized REE distribution pattern of volcanic rocks from Johor National Park, Endau Rompin.

profile. Majority of the analysed rocks displayed striking uniformity in their REE pattern shapes and Eu anomalies except that the granite profile has a wider range of rock/chondrite. Eu anomaly

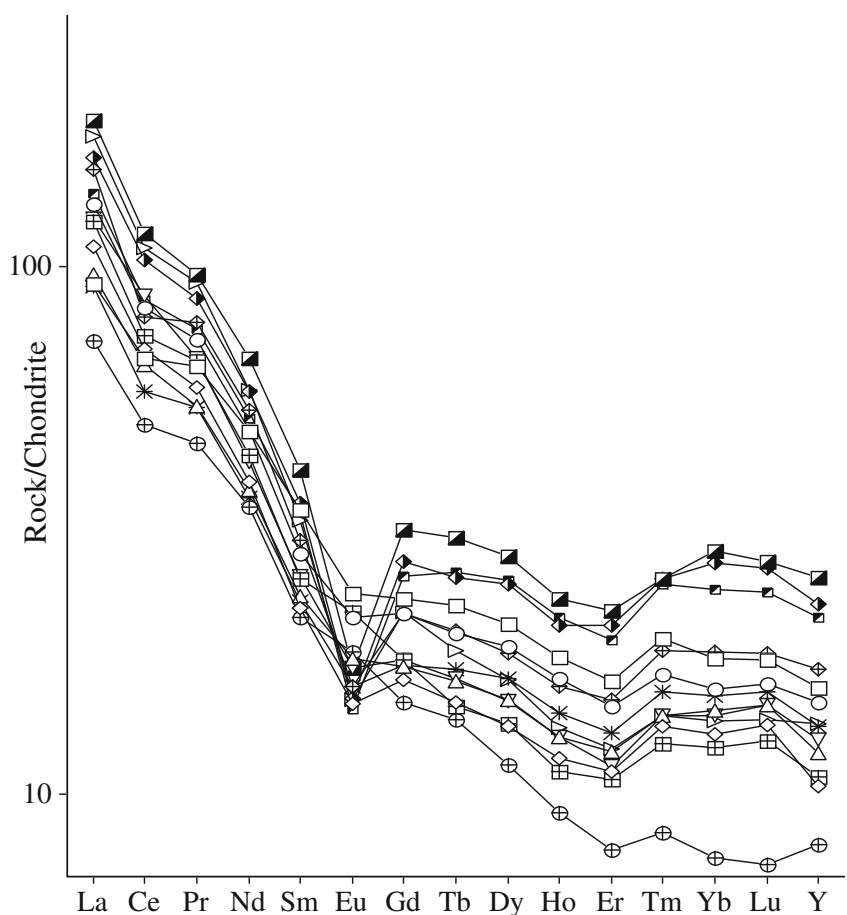

Figure 10. Chondrite normalized REE distribution pattern of granitic rocks from Johor National Park, Endau Rompin.

does not show any trend with increasing or decreasing $\mathrm{SiO}_{2}$. The LREE in both granite and volcanic samples typically have 90 to 110 times chondrite levels, whereas the HREE have 6 to 50 times chondrite levels. In general, the chondrite-normalized REE pattern for the granitic rocks is parallel to that of the volcanic $\left(\mathrm{La}_{\mathrm{N}} \approx 250, \mathrm{Yb}_{\mathrm{N}} \approx 15\right)$ with a strong LREE/HREE fractionation $\left((\mathrm{La} / \mathrm{Yb})_{\mathrm{N}}\right.$ from 20 to 60) and small Eu anomaly. Some of the granite samples show a concave shape profile which is consistent with liquids produced by partial melting of quartz feldspathic rocks containing amphibole among the residual phase.

The importance of sphene, zircon, allanite, apatite and monazite is shown in the $(\mathrm{La} / \mathrm{Yb})_{\mathrm{N}}$ versus La diagram (figure 11). Also shown is the vector diagram representing the net change in composition of the liquid after $15 \%$ Rayleigh fractionation by removing sphene, zircon, allanite, apatite or monazite. The volcanic samples show a good trend with crystallization options controlled by monazite, allanite or apatite or combination of these minerals. The granitic samples show a rather scattered trend which makes it difficult to predict their mineral crystallization option. The geochemical difference between the granite and volcanic magmas are also shown in spider diagram plots (figure 12). On the primitive mantle (Sun and McDonough 1989) normalized spider diagram (figure 12a), the granite samples show a strong depletion in $\mathrm{Ba}, \mathrm{Ce}, \mathrm{Sr}, \mathrm{P}, \mathrm{Zr}$, Ti and enrichment 


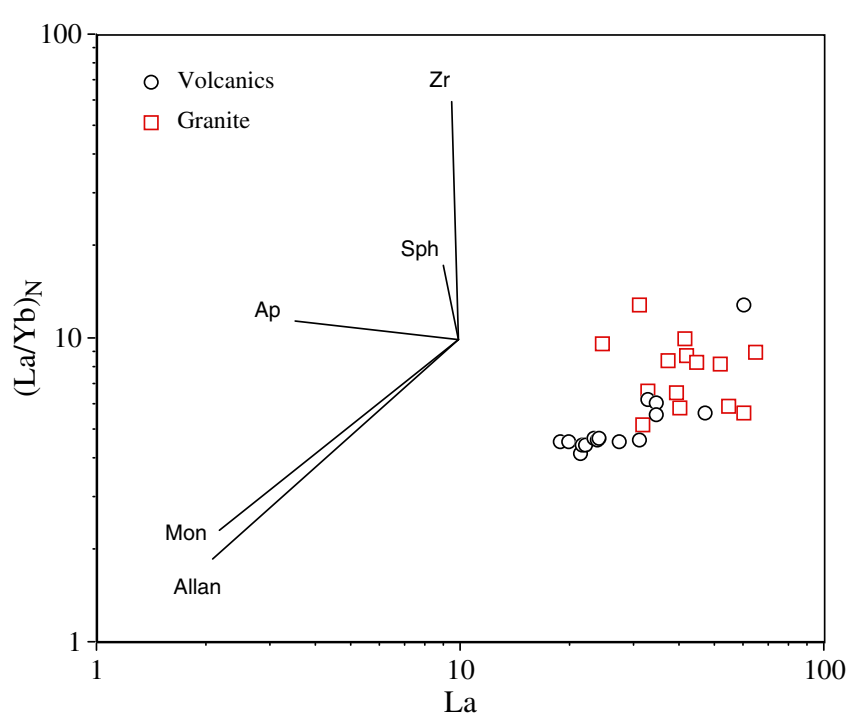

Figure 11. La vs. $(\mathrm{La} / \mathrm{Yb})_{\mathrm{N}}$ plot of the volcanic and granitic rocks from Johor National Park, Endau Rompin. Mineral vectors indicate path evolved liquids for $15 \%$ of a mineral precipitating: $\mathrm{Pl}=$ plagioclase; $\mathrm{Kf}=\mathrm{K}$-feldspar; $\mathrm{Qz}=$ quartz; Mt = magnetite.
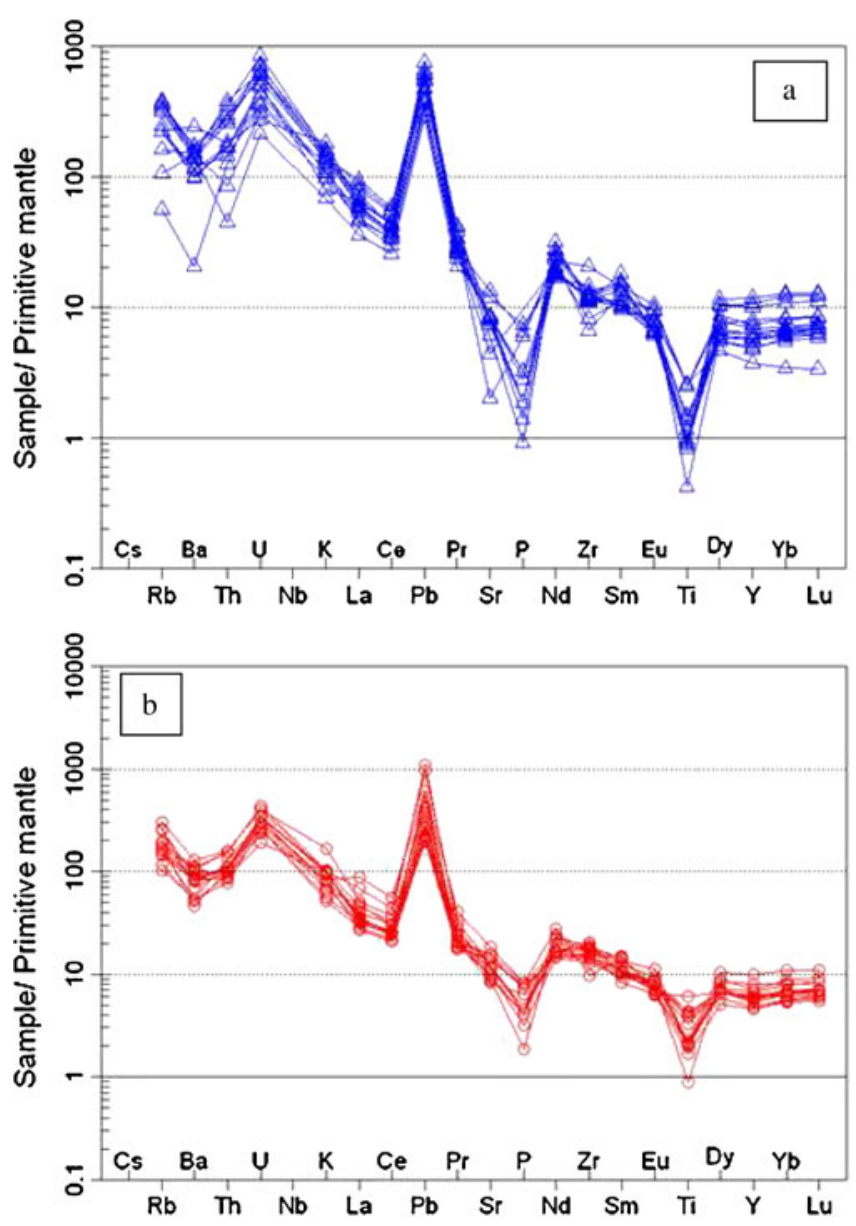

Figure 12. Spider plot for (a) granitic and (b) volcanic rocks from the study area. in $\mathrm{U}, \mathrm{P}$ and $\mathrm{Nd}$. The volcanic profile show depletion in $\mathrm{Ba}, \mathrm{Ce}, \mathrm{P}$ and $\mathrm{Ti}$ and enrichment in $\mathrm{U}, \mathrm{Pb}$ and $\mathrm{Nd}$.

\subsection{Rock classification}

In general, mineralogy of the granitic rock, especially the occurrence of sphene and hornblende also suggest that they are of ' $\mathrm{I}$ ' type. This is supported by $\mathrm{ACNK}\left(\mathrm{Al}_{2} \mathrm{O}_{3} / \mathrm{CaO}+\mathrm{Na}_{2} \mathrm{O}+\mathrm{K}_{2} \mathrm{O}\right)$ values where all the granitic samples analysed are well below $\mathrm{ACNK}=1.1$ (figure 13) and have increasing ACNK values with $\mathrm{SiO}_{2}$, both features suggested that the granite magma originate from igneous source (Shand 1943; Chappell and White 1992). In the $\mathrm{Na}_{2} \mathrm{O}$ versus $\mathrm{K}_{2} \mathrm{O}$ diagram (figure 14), all the Endau Rompin granite samples plot in the I type field implying that the magma source is of igneous origin. The majority of the volcanic samples also plot in the same field. Thus, the granitic rock from the study area is of the same granite type as other granitic rocks in the Eastern Belt Granite of Peninsular Malaysia, which could also be broadly classified as I type granite. The I type nature of both granite and volcanic rocks are also shown by the $\mathrm{P}_{2} \mathrm{O}_{5}$ versus $\mathrm{SiO}_{2}$ plot (Chappell 1999). He showed that the most distinctive difference between the compositions that result from the crystal fractionation of felsic I and $\mathrm{S}$ type melts is that with increasing $\mathrm{SiO}_{2}, \mathrm{P}$ decreases in $\mathrm{I}$ type and increases in $\mathrm{S}$ type melts. In the plot (figure 15), both $\mathrm{P}_{2} \mathrm{O}_{5}$ in both granite and volcanic samples decrease with increasing $\mathrm{SiO}_{2}$. The I type nature of both magmas suggested that they share a similar type of source, that is, igneous rock (Chappell and White 1974, 1992; Chappell and Stephens 1988; Chappell

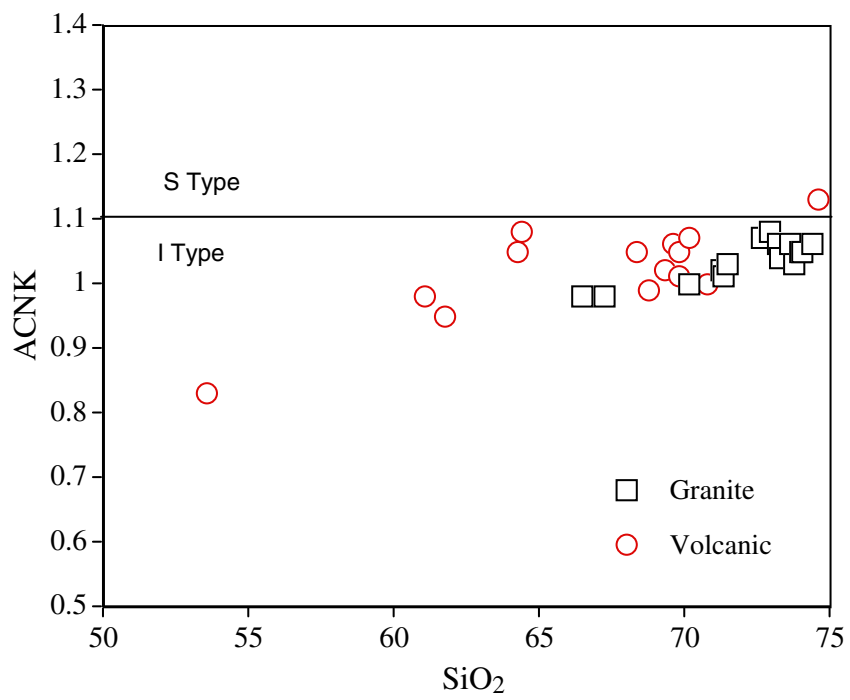

Figure 13. ACNK vs. $\mathrm{SiO}_{2}$ plot for granite and volcanic from the Endau Rompin area. 


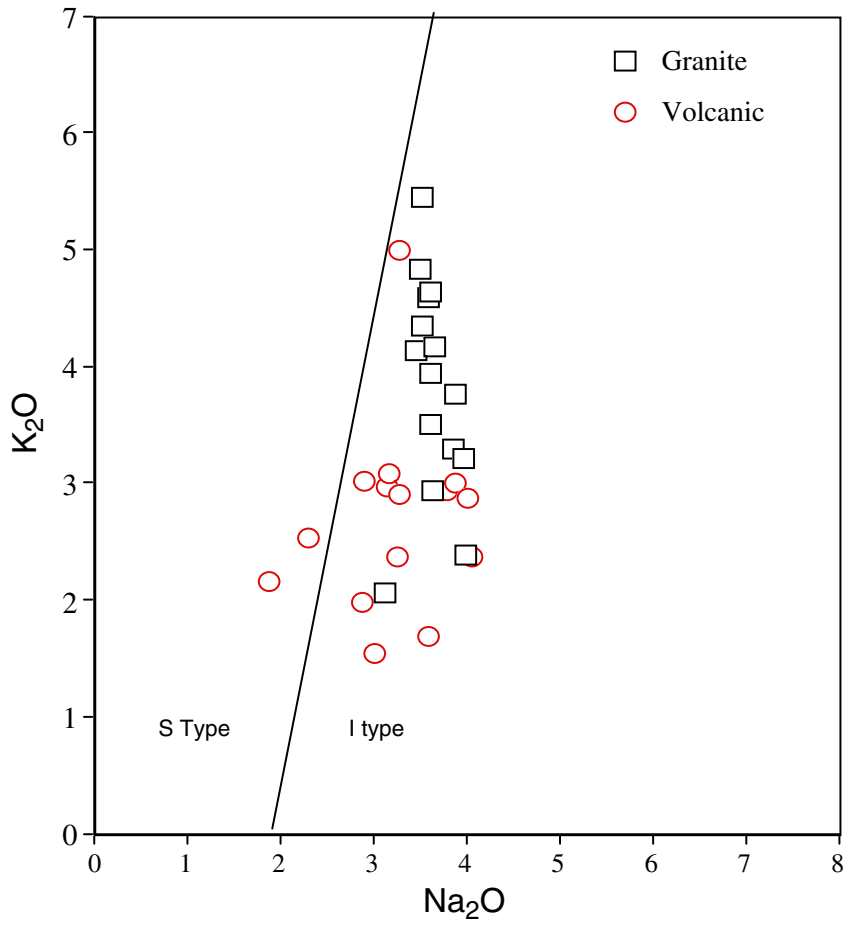

Figure 14. $\mathrm{Na}_{2} \mathrm{O}$ vs. $\mathrm{K}_{2} \mathrm{O}$ plot for granite and volcanic from the Endau Rompin area.

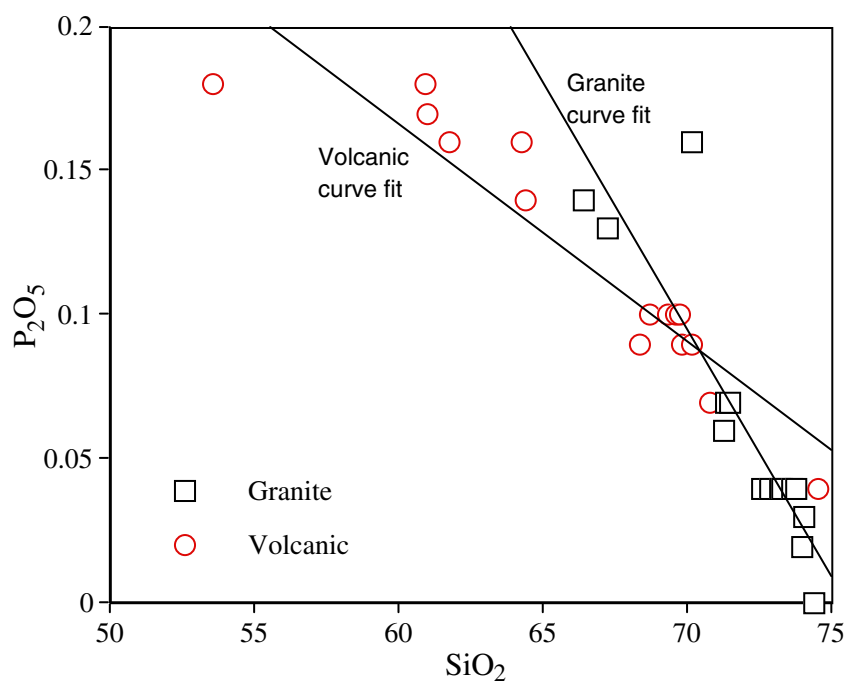

Figure 15. $\mathrm{P}_{2} \mathrm{O}_{5}$ vs. $\mathrm{SiO}_{2}$ plot for granite and volcanic from the Endau Rompin area. The curve fit indicates the decreasing trends of both volcanic and granitic samples.

1999). However, the fact that the volcanic rocks is older (Permian) than the granitic (Triassic) rocks, suggest that the source rock could also be different in terms of age.

\subsection{Tectonic implication}

De la Roche et al. (1980) proposed a classification scheme for volcanic and plutonic rocks based upon their cationic proportions of major elements, expressed as millications. The diagram is an $X-Y$ bivariate graph using the plotting parameters $R 1$ and $R 2$ where:

$$
\begin{gathered}
R 1=4 \mathrm{Si}-11(\mathrm{Na}+\mathrm{K})-2(\mathrm{Fe}+\mathrm{Ti}) \\
R 2=\mathrm{Al}+2 \mathrm{Mg}+6 \mathrm{Ca}) .
\end{gathered}
$$

Batchelor and Bowden (1985) showed that the diagram can discriminate five granitic groups related to the tectonomagmatic divisions proposed by Pitcher (1979, 1983).

The granite samples plot in the syn-collisional field, whereas majority of the volcanic samples plot in pre-plate collision field (figure 16). The results agree with the age of both granite and volcanic magmatism and tectonic scenario of Peninsular Malaysia (Metcalfe 2000). Subduction of the Sibumasu eastward beneath the Indochina blocks in Peninsular Malaysia during Permian to Triassic produced volcanic and granitic magmatism broadly known as East Malaya Volcanic Arc and Eastern Belt granite, respectively (Metcalfe 2000). Triassic volcanic arc (East Malaya Volcanic Arc) is identified as an elongate strip to the east of the Bentong Raub suture through eastern Peninsular Malaysia which includes the studied area volcanic rocks. It is suggested that the volcanism in the study area was produced at the beginning of the subduction process. On the other hand, the granitic magmatism (including the granitic rocks from the study area) was formed at the final stage of the subduction.

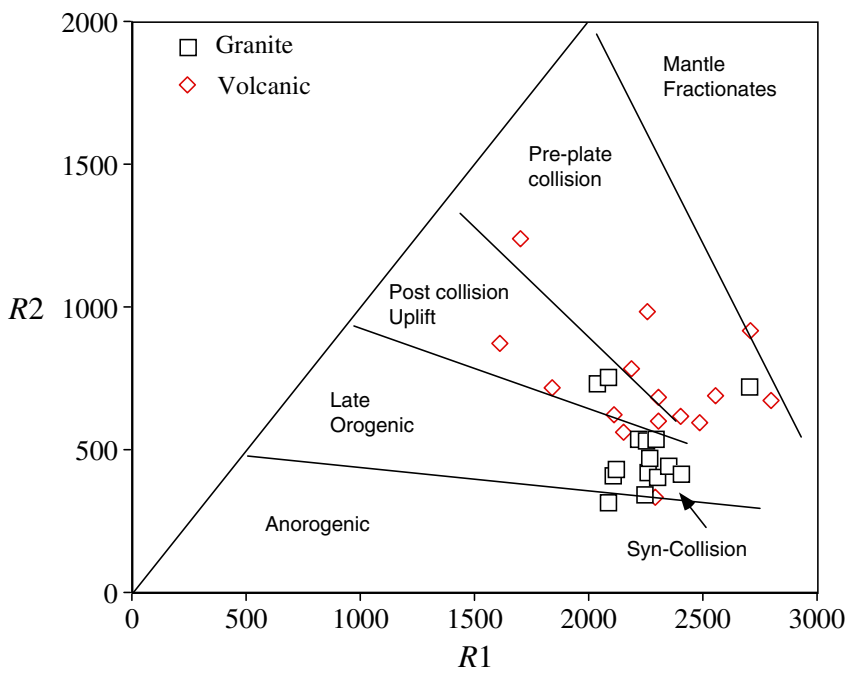

$R 1=4 \mathrm{Si}-11(\mathrm{Na}+\mathrm{K})-2(\mathrm{Fe}+\mathrm{Ti})$

$R 2=6 \mathrm{Ca}+2 \mathrm{Mg}+\mathrm{Al}$

Figure 16. $\mathrm{R} 1=(4 \mathrm{Si}-11(\mathrm{Na}+\mathrm{K})-2(\mathrm{Fe}+\mathrm{Ti}))$ vs. $\mathrm{R} 2=$ $(\mathrm{Al}+2 \mathrm{Mg}+6 \mathrm{Ca})$ diagram for the granite and volcanic rocks from the study area. 


\section{Conclusions}

The close spatial and chemical association between the volcanic and granitic rocks in the study area supports suggestions of a comagmatic relationship between these two rock suites. However, the vast difference in age between both volcanic and granitic rocks and the occurrence of granitic block in volcanic rocks strongly suggested that they both have uncommon origin. Both magmas produced at different times are separated by about $\sim 50$ Ma. Geochemical study also shows that the granite and volcanic magmas have some significant difference, which suggests that they have different sources. Among them are:

- The difference in crystallizing option as shown in $\mathrm{TiO}_{2}$ versus $\mathrm{Zr}$ and $(\mathrm{La} / \mathrm{Yb})_{\mathrm{N}}$ versus $\mathrm{La}$ diagrams (figures 7 and 11, respectively). For $\mathrm{TiO}_{2}$ versus $\mathrm{Zr}$, the evolution of volcanic magma is controlled by a combination of plagioclase $+\mathrm{K}$ feldspar + quartz + magnetite + sphene (trend 1) and zircon + hornblende + sphene + magnetite (trend 2), whereas the granitic magmas are controlled by crystallization of zircon + hornblende + sphene + magnetite. In $(\mathrm{La} / \mathrm{Yb})_{\mathrm{N}}$ versus La diagram, monazite, allanite or apatite or a combination of these minerals controlled the abundance of REE in volcanic magma but no trend was shown by the granitic magma samples.

- The granite profile has a wider range of HREE and more concave-shaped profile compared to the volcanic profile. The granite profile is consistent with liquids produced by partial melting of quartz feldspathic rocks containing amphibole.

- Both magmas have different behaviour in trace elements as shown in figure 12.

The granite is similar to the Eastern Belt Granite, particularly in the presence of hornblende and sphene and high $\mathrm{Na}_{2} \mathrm{O}$ content. Of particular interest are the granitic rocks, with some of the samples containing more $1000 \mathrm{ppm} \mathrm{Ba}$. This feature is common in the intermediate rocks from the central belt of Peninsular Malaysia (Mustafa Kamal and Ghani 2003). The rocks are syenite, monzonite and gabbro associated with the Benom Igneous Complex, containing up to $10000 \mathrm{ppm}$ Ba. The high Ba content of the central belt rocks results from penetration of the lower lithosphere by small volumes of mantle material that is enriched in those elements (Green and Wallace 1988; Ionov et al. 1993; Rudnick et al. 1993). Both volcanic and granitic magmas show a steep trend in the La/Sm versus La diagram (figure 17) suggesting that the effects of partial melting and source composition were more important than fractional crystallization in controlling

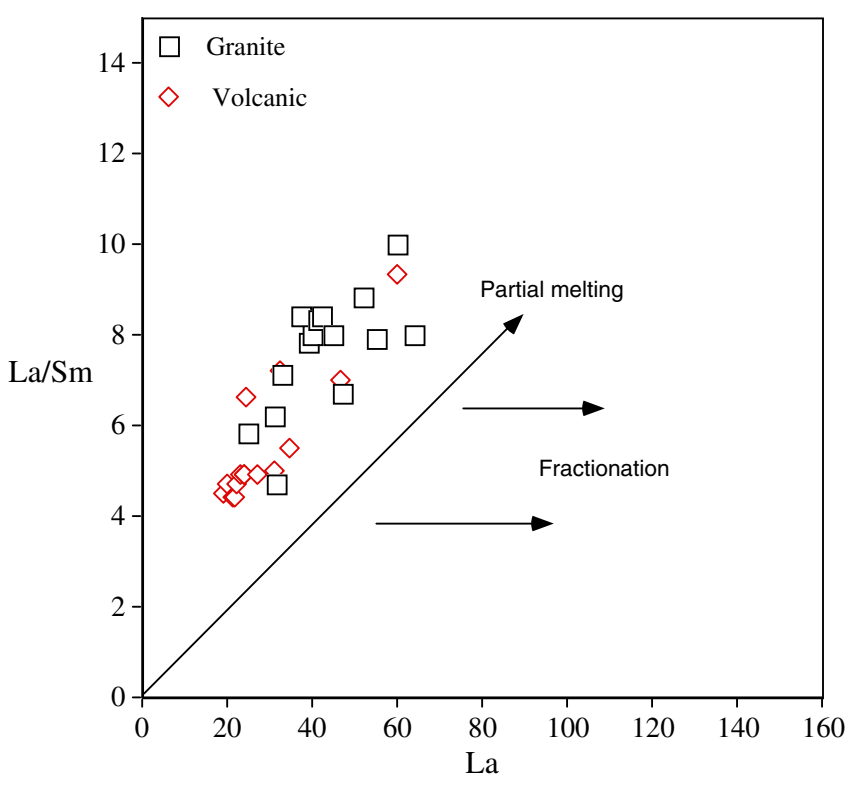

Figure 17. La/Sm vs. La plot for granite and volcanic from the Endau Rompin area.

the compositional variation in both magmas (Jiang et al. 2005).

\section{Acknowledgements}

The authors thank the staff of the National Park Department and Perhilitan Department for providing accommodation at the Selai Base Camp, Johore National Park, Endau Rompin. This project was funded by University of Malaya research grants F0739/2002A, F0727/2002A and RG041/09AFR. Mohd Anuar Ismail and Mohd Azamie are thanked for field assistance. Dr N A Majid is thanked for reviewing the manuscript.

\section{References}

Atherton M P, Mahawat C and Brotherton M S 1992 Integrated chemistry, textures, phase relations and modelling of a composite granodioritic-monzonitic batholith, Tak, Thailand; J. Southeast Asian Earth Sci. 7(2/3) 89-112.

Bignell J D and Snelling N J 1977 Geochronology of Malayan granites; Overseas Geol. Mineral. Resour. 4771.

Batchelor R A and Bowden P 1985 Petrogenetic interpretation of granitoid rock series using multicationic parameters; Chem. Geol. 48 43-55.

Chappell B W 1999 Aluminium saturation in I- and S-type granites and characterization of fractionated haplogranites; Lithos 46(3) 535-551.

Chappell B W and Stephens W E 1988 Origin of infracrustal (I-type) granite magmas; Trans. Roy. Soc. Edin. Earth Sci. 79 71-86.

Chappell B W and White A J R 1974 Two contrasting granite types; Pacific Geol. 8 173-174.

Chappell B W and White A J R 1992 I- and S- type granites in the Lachlan fold belt; Trans. Roy. Soc. Edin. Earth Sci. 83 1-26. 
Chong F S, Cook R H, Evans M G and Suntharalingam T 1968 Geology and mineral resources of Melaka-Mersing Area; Ann. Rep. Geol. Surv. Malaysia, pp. 89-94.

Cobbing E J, Pitfield P E J, Darbyshire D P F and Mallick D I J 1992 The granites of the south-east Asian tin belt; Overseas Memoir 10, British Geological Survey.

De la Roche H, Leterrier J, Grande Claude P and Marchal M 1980 A classification of volcanic and plutonic rocks using R1-R2 diagrams and major elements analyses - its relationship and current nomenclature; Chem. Geol. 29 $183-210$.

Foo KY 1969 Reconnaissance geological survey of area "A", southeast Pahang; Ann. Rep. Geol. Surv. Malaysia pp. 95-97.

Ghani A A 2009 Volcanism; In: Geology of Peninsular Malaysia (eds) Hutchison C S and Tan D N K, pp. 197-210.

Ghani A A, Yusoff I and Hassan M H A 2007 Geology and geochemistry of volcanic and granitic rocks from the southwestern region of Endau Rompin National Park, Johor Malaysia; In: The forest and biodiversity of Selai Endau Rompin (eds) Mohamed H and Zakaria-Ismail M, University Malaya, Geol. Soc. Malaysia, Kuala Lumpur.

Green D H and Wallace M E 1988 Mantle metasomatism by ephemeral carbonatite melts; Nature 336 459-462.

Hutchison C S 1977 Granite emplacement and tectonic subdivision of Peninsular Malaysia; Bull. Geol. Soc. Malaysia 9 197-207.

Hutchison C S and Tan D N K (eds.) 2009 Geology of Peninsular Malaysia; University of Malaya \& Geological Society of Malaysia, 480p.

Ionov D A, Dupuy C, O'Reilly S Y, Koplova M G and Genshaft Y S 1993 Carbonated peridotite xenoliths from Spitsbergen: Implication for trace element signiture of mantle carbonate metasomatism; Earth Planet. Sci. Lett. $119283-297$.

Jiang Y H, Ling H F, Jiang S Y, Fan H H, Shen W Z and Ni P 2005 Petrogenesis of a Late Jurassic Peraluminous Volcanic Complex and its high-Mg, potassic, quenched enclaves at Xiangshan, Southeast China; J. Petrol. 46(6) 1121-1154.

Le Bas M J, Le Maitre R W, Streickeisen A and Zanettin B 1986 A chemical classification of volcanic rocks based on the total alkali-silica diagram; J. Petrol. 27 745-750.

Le Maitre RW (ed.) 2002 Igneous rocks, a classification and glossary of terms; Recommendations of the International Union of Geological Sciences Subcommission on the Systematics of Igneous Rocks; (Cambridge, UK: Cambridge University Press).

Masuda A, Nakamura N and Tanaka T 1973 Fine structures of mutually normalized rare-earth patterns of chondrites; Geochim. Cosmochim. Acta 38 239-248.

Metcalfe I 2000 The Bentong-Raub suture zone; J. Asian Earth Sci. 18 691-712.

Mustafa Kamal S and Ghani A A 2003 High Ba Sr rocks from the Central Belt of Peninsular Malaysia and its implication; Bull. Geol. Soc. Malaysia 46 365371.

Pitcher W S 1979 The nature, ascent and emplacement of granitic magmas; J. Geol. Soc. London 136 627-662.

Pitcher W S 1983 Granite type and tectonic environment; In: Mountain building processes (ed.) Hsu K (London: Academic Press), pp. 19-40.

Roberts M P and Clemens J D 1993 Origin of highpotassium, calc alkaline, I-type granitoids; Geol. 21 $825-828$.

Rudnick R L, Mc Donough W F and Chappell B W 1993 Carbonatite metasomatism in the northern Tanzanian mantle: Petrographic and geochemical characteristics; Earth Planet. Sci. Lett. 114 463-475.

Shand S J 1943 Eruptive rocks, 2nd edn (London: T. Murby and Company), 444p.

Streckeisen A L 1976 To each plutonic rock its proper name; Earth Sci. Rev. 12 1-33.

Sun S-S and McDonough W F 1989 Chemical and isotopic systematics of oceanic basalts: Implications for mantle composition and processes; Geol. Soc. London Spec. Publ. $42313-345$. 